\title{
Vulnerability Analysis of Ancient Timber Architecture by Considering the Correlation of Different Failure Modes
}

\author{
Junhong Huan $\mathbb{D}$, ${ }^{1,2}$ Donghui $M a,{ }^{1,2}$ and Wei Wang $\mathbb{C}^{1,2}$ \\ ${ }^{1}$ Institute of Earthquake Resistance and Disaster Reduction, Beijing University of Technology, Beijing 100124, China \\ ${ }^{2}$ Key Scientific Research Base of Safety Assessment and Disaster Mitigation for Traditional Timber Structure \\ (Beijing University of Technology), State Administration for Cultural Heritage, Beijing 100124, China
}

Correspondence should be addressed to Wei Wang; ieeww@bjut.edu.cn

Received 26 September 2018; Revised 15 November 2018; Accepted 29 November 2018; Published 10 December 2018

Academic Editor: Łukasz Jankowski

Copyright (C) 2018 Junhong Huan et al. This is an open access article distributed under the Creative Commons Attribution License, which permits unrestricted use, distribution, and reproduction in any medium, provided the original work is properly cited.

\begin{abstract}
The paper proposes an innovative method of analyzing the seismic fragility of ancient timber architecture. The method is based on the Copulas, in which correlation between different failure modes is considered. This method is applied to assess the vulnerability of ancient timber architecture in Ming dynasty. The assessment includes four steps. In the first step, the incremental dynamic analysis is employed to establish seismic vulnerability curves of different failure modes for the structure. After that, Copula joint distribution function is used to analyze the correlation among different failure modes. In the third step, fragility curves considering correlation among different failure modes are established. In the last step, the fragility curves are compared with those obtained by first-order bound method. The results show that seismic vulnerability of ancient timber architecture based on the Copulas is greater than that of any single failure modes. Moreover, the occurrence probability ranges between the upper and lower boundaries of the first-order bound method, but is close to the lower boundary.
\end{abstract}

\section{Introduction}

Many buildings of ancient timber architecture are listed as cultural heritage sites for their historical, artistic, and cultural value. Carved beams, painted rafters, painting, and colored drawings are valuable parts of ancient timber architecture [1]. However, according to [2-4] many precious ancient buildings have been damaged and even destroyed in earthquakes alone, causing great economic and cultural loss. Therefore, it is essential to perform a seismic fragility analysis for these structures.

Seismic fragility analysis is a quantitative method that has been widely used in antiseismic analysis of buildings. Fragility curves describe seismic response of buildings from the perspective of probability. Some researchers $[5,6]$ used this method to analyze vulnerability of RC structures. Macabuag et al. [7] built tsunami fragility curves for buildings. A simplified model of ancient timber architecture was built by Kouris et al. [8]. Seismic fragility curves of the architecture were established by nonlinear finite element analysis. The analysis showed that the traditional ancient architecture had good deformation and seismic capacities. Faye et al. [9] established seismic fragility curves of a traditional timberframe wall by nonlinear spectrum analysis, and it showed the wall had a good mechanical property. Ahmad et al. [10] analyzed the vulnerability of three traditional timber-frame masonry structures, and the results showed that this kind of structure was suitable in the limit of peak ground acceleration $(P G A)<0.7 g$.

Interstory drift ratio of building is usually selected as the only seismic demand parameter to build seismic fragility curves. Under this situation, this method could examine only one failure mode. Given the complex structure and mechanical properties [11], ancient timber architecture could have more than one failure model. Therefore, different seismic demand parameters [12] should be adopted to construct the seismic fragility curves. In the seismic vulnerability analysis, effects caused by correlation among different failure modes on structure vulnerability need to be considered.

Sklar's theorem [13] is the theoretical foundation for the Copula usage, which can describe the linear and nonlinear correlation between different failure modes. Copulas have 
been widely used in a variety of applications. Fengler and Okhrin [14] used Copulas to capture salient features of multivariate dependence for risk-management purposes. Peng et al. [15] used Copulas to improve flood risk for confluence flooding control downstream of a reservoir. Yang et al. [16] applied Copulas to assess fatigue reliability of Yangtze River Bridge.

In this study, a vulnerability analysis model of Chinese traditional timber architecture is built. Based on Gaussian Copula, t Copula, and Frank Copula, the correlation between different failure modes is taken into account. The model is applied to evaluate the vulnerability of Chinese ancient timber architecture, so as to provide a reference for practical engineering.

\section{Definition of Seismic Fragility of Ancient Timber Architecture}

Seismic fragility of an ancient timber architecture is the occurrence probability of a certain state of the structure under different forcing intensities. The fragility is defined as a probability of the structural seismic demand $S_{n}$ exceeding capacity $S_{r}$ under the condition of a given level of intensity measure of the hazard [17]. It is given by the following.

$$
P_{f}=P_{r}\left(\frac{S_{n}}{S_{r}} \leq 1\right)
$$

It is generally assumed that the structural demand parameter follows the lognormal distribution [18] and $S_{n}=$ $\ln \left(\widetilde{S_{n}}, \beta_{n}\right), S_{r}=\ln \left(\widetilde{S_{r}}, \beta_{r}\right) . \widetilde{S_{n}}$ is the average ductility, $\widetilde{S_{r}}$ is the average value of the seismic demand, $\beta_{n}$ is the logarithmic standard deviation of $S_{n}$, and $\beta_{r}$ is the logarithmic standard deviation of $S_{r}$.

Cornell et al. [19] revealed that there is an exponential relation between $\widehat{S_{n}}$ and ground motion parameter $I$, which can be expressed as

$$
\widetilde{S_{n}}=a I^{b}
$$

where $I$ is a ground motion parameter; $a$ and $b$ are constant terms.

Taking logarithms on both sides of (2), we get the following.

$$
\ln \left(\widetilde{S_{n}}\right)=b \ln (I)+\ln (a)
$$
follows:

The fragility curve for a specific state of damage is as

$$
P_{f}=\Phi\left[\frac{-\ln \left(S_{n} / S_{r}\right)}{\sqrt{\beta_{n}^{2}+\beta_{r}^{2}}}\right]=\Phi\left[\frac{b \ln I+\ln a-\ln \widetilde{S_{n}}}{\sqrt{\beta_{n}^{2}+\beta_{r}^{2}}}\right]
$$

where $\Phi[\bullet]$ is the standardized normal distribution. The fragility curves under different failure modes can be constructed by (4).

In this study, a new advanced methodology for obtaining the analytical fragility curves of ancient timber architecture is proposed. The method is based on the Copulas, in which correlation between different failure modes is considered.

\section{Failure Modes of Ancient Timber Architecture Based on Copulas}

3.1. Definition of Copulas. If $X_{1}, X_{2}, \ldots, X_{N}$ are continuous random variables with continuous distribution functions $F_{x_{1}}\left(x_{1}\right), \ldots, F_{x_{N}}\left(x_{N}\right)$, the Copulas $C\left(x_{1}, x_{2}, \ldots, x_{N}\right)$ are given by

$$
\begin{aligned}
& F\left(x_{1}, x_{2}, \ldots, x_{N}\right) \\
& \quad=C\left[F_{x_{1}}\left(x_{1}\right), F_{x_{2}}\left(x_{2}\right), \ldots, F_{x_{N}}\left(x_{N}\right)\right]
\end{aligned}
$$

where $F\left(x_{1}, x_{2}, \ldots, x_{N}\right)$ is the joint distribution function of $X_{1}, X_{2}, \ldots, X_{N}$. This indicates that a Copula connects the marginal distributions to the joint distribution. If $F_{x_{1}}\left(x_{1}\right), \ldots, F_{x_{N}}\left(x_{N}\right)$ are continuous, then $C\left(x_{1}, x_{2}, \ldots, x_{N}\right)$ is unique.

There are many kinds of Copulas, of which t Copula, Gaussian Copula, and Archimedean Copula are commonly used.

3.2. Joint Bivariate Distribution Functions of Copulas. A bivariate Copula $C(u, v)$ is defined on the unit square $[0,1]^{2}$. Let $x_{1}$ and $x_{2}$ be two random variables, with marginal cumulative distribution functions $F_{1}\left(x_{1}\right)$ and $F_{2}\left(x_{2}\right)$, respectively. And let $F\left(x_{1}, x_{2}\right)$ be a joint cumulative distribution function of $x_{1}$ and $x_{2}$. Then,

$$
F\left(x_{1}, x_{2}\right)=C\left(F_{1}\left(x_{1}\right), F_{2}\left(x_{2}\right) ; \theta\right)=C(u, v ; \theta)
$$

where $u=F_{1}\left(x_{1}\right), v=F_{2}\left(x_{2}\right), C(\bullet)$ is Copula function, and $\theta$ is Copula parameter.

Let $f_{1}\left(x_{1}\right)$ and $f_{2}\left(x_{2}\right)$ be the density functions of $x_{1}$ and $x_{2}$, respectively. Then, the joint density function $f\left(x_{1}, x_{2}\right)$ is as follows:

$$
\begin{aligned}
f\left(x_{1}, x_{2}\right) & =f_{1}\left(x_{1}\right) \cdot f_{2}\left(x_{2}\right) \\
& \bullet c\left(F_{1}\left(x_{1}\right), F_{2}\left(x_{2}\right) ; \theta\right) \\
c\left(F_{1}\left(x_{1}\right), F_{2}\left(x_{2}\right) ; \theta\right)= & \frac{\partial^{2} C(u, v ; \theta)}{\partial u \partial v}
\end{aligned}
$$

where $c(\bullet)$ is bivariate Copula density of $C(\bullet)$.

Rank correlations are Copula-based dependence measures, and the Kendall rank correlation coefficient can be taken as a measure of concordance for bivariate random variables. In this study, Kendall rank correlation coefficient $\tau$ was used to calculate the Copula parameter $\theta$. The study carried out by Nelsen [20] shows that relation between $\tau$ and $\theta$ is as follows.

$$
\tau=4 \int_{0}^{1} \int_{0}^{1} C(u, v ; \theta) d C(u, v ; \theta)-1
$$

3.3. Joint Bivariate Collapse Probability Using Copula Approach. In a bivariate series system, if $g_{1}$ and $g_{2}$ are the structural performance functions of ancient timber architecture for different collapse modes, then, the probability of the simultaneous occurrence of two collapse modes is given as follows.

$$
P\left[g_{1}(X) \leq 0, g_{2}(X) \leq 0\right]=C\left(P_{f 1}, P_{f 2}\right)
$$


The collapse probability of the bivariate series system is given by

$$
\begin{aligned}
P_{f s}= & \left.P\left[g_{1}(X) \leq 0 \cup g_{2}(X) \leq 0\right]\right] \\
= & P\left(g_{1}(X) \leq 0\right)+P\left(g_{1}(X) \leq 0\right) \\
& -P\left[g_{1}(X) \leq 0, g_{2}(X) \leq 0\right] \\
= & P_{f 1}+P_{f 2}-C\left(P_{f 1}, P_{f 2}\right)
\end{aligned}
$$

where $P_{f 1}, P_{f 2}$ are the collapse probabilities of two collapse modes, respectively.

t Copula, Gaussian Copula, and Frank Copula are used to compute the fragility curves of the ancient timber structure architecture in this study, which are as follows:

(1) Bivariate t Copula

$$
\begin{aligned}
& C_{t}(u, v ; \theta, k)=\int_{-\infty}^{t_{k}^{-1}\left(\mu_{1}\right)} \int_{-\infty}^{t_{k}^{-1}\left(\mu_{2}\right)} \frac{1}{2 \pi \sqrt{1-\theta^{2}}}[1 \\
& \left.+\frac{s^{2}-2 \theta s t+t^{2}}{k\left(1-\theta^{2}\right)}\right] d s d t
\end{aligned}
$$

(2) Bivariate Gaussian Copula

$$
\begin{aligned}
& C_{G}(u, v) \\
& =\int_{-\infty}^{\Phi^{-1}\left(\mu_{1}\right)} \int_{-\infty}^{\Phi^{-1}\left(\mu_{2}\right)} \frac{1}{2 \pi \sqrt{1-\theta^{2}}} e^{\left[-\left(\left(s^{2}-2 \theta s t+t^{2}\right) / 2\left(1-\theta^{2}\right)\right)\right]} d s d t
\end{aligned}
$$

(3) Bivariate Frank Copula

$$
C_{F}(u, v)=-\frac{1}{\theta} \ln \left[1+\frac{\left(e^{-\theta \mu_{1}}-1\right)\left(e^{-\theta \mu_{2}}-1\right)}{e^{-\theta}-1}\right]
$$

where $t_{k}^{-1}$ is the inverse function of the $t$ distribution with $k$ degree and $\Phi^{-1}$ is the inverse function of the standardized normal distribution function.

\section{Seismic Fragility Analysis Process of Ancient Timber Architecture Based on Copulas}

A new methodology for obtaining fragility curves of ancient timber architecture is proposed in this study. This method is based on Copulas, in which effect of correlation between different failure modes on the vulnerability of the whole structure is considered. The process of analysis is as follows: First, two different seismic demand parameters are selected. Then, incremental dynamic analysis is employed to establish seismic vulnerability curves of different failure modes for the structure. Next, Copula parameters are calculated by (9). Forth, Copula joint distribution function is used to analyze the correlation among different failure modes. Finally, fragility curves considering correlation among different failure modes are established.

\section{Case Study}

5.1. Description of the Architecture. The case in study is the rear hall of Huashi Fire God Temple which is located in

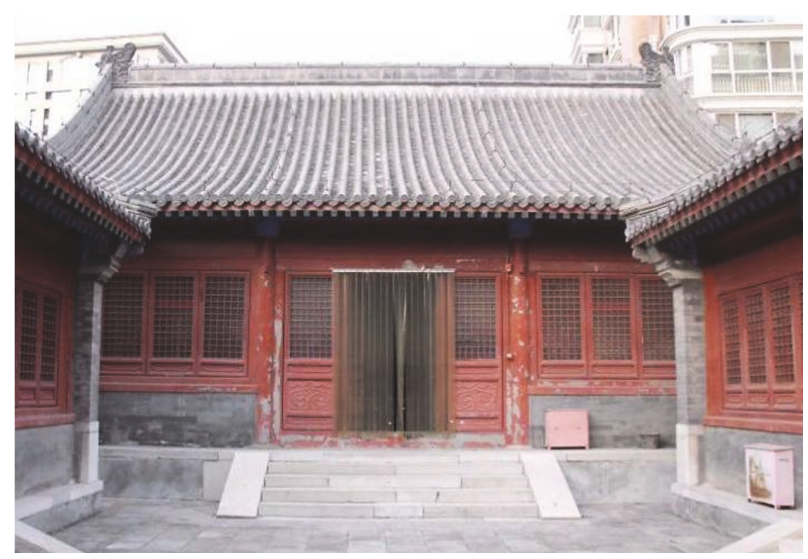

Figure 1: Elevation of Huashi Fire God Temple.

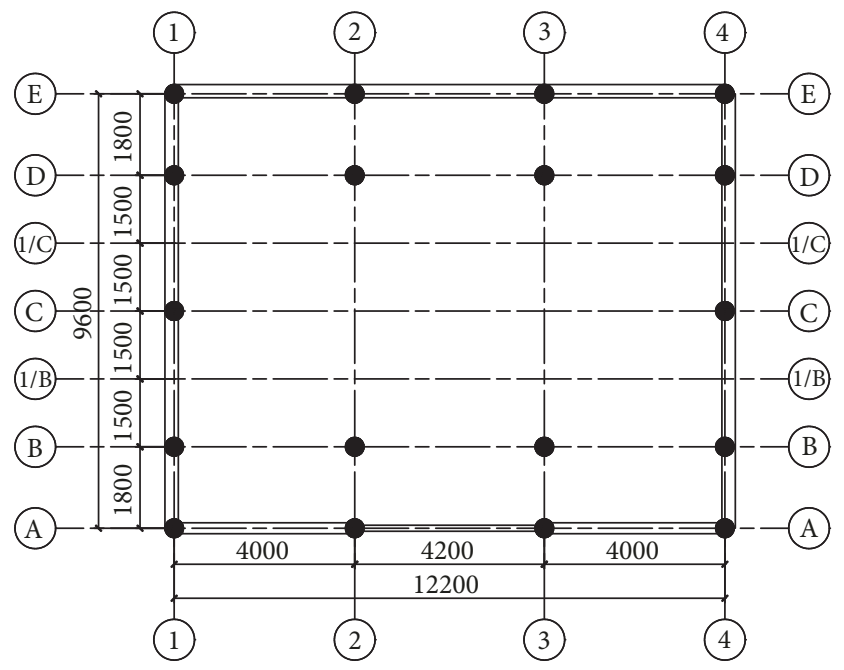

FIgure 2: Plane layout of Huashi Fire God Temple.

Chongwenmen, Dongcheng District, Beijing. It was built during the rule of the Ming Dynasty and has a history of almost 450 years. The structure was damaged over the years and was renovated during the reign of Emperor Qianlong of the Qing dynasty. In 2004, the building was renovated again by the government. The total area of the Huashi Fire God Temple is $543.44 \mathrm{~m}^{2}$ and that of the rear hall is $132.2 \mathrm{~m}^{2}$. The rear hall is a single storied structure with a post and lintel wood frame and a Yingshan Roof. The heights of eaves, ridge, and stylobate are $3.7 \mathrm{~m}, 7.0 \mathrm{~m}$, and $0.7 \mathrm{~m}$, respectively. Details of the size of the building can be obtained from [21]. Elevation and plane graphs of Huashi Fire God Temple are shown in Figures 1 and 2.

Yin et al. [22] proposed a method to estimate the volume of historical timber-frame buildings in China. Referring to this research, an on-site test was carried out for the rear hall. The results show no obvious decay on the surface of timber components. There are local damages on wall. Some of the wood components are cracked and several of the plinths are damaged. The damaged appearance of the building is shown in Figure 3. 


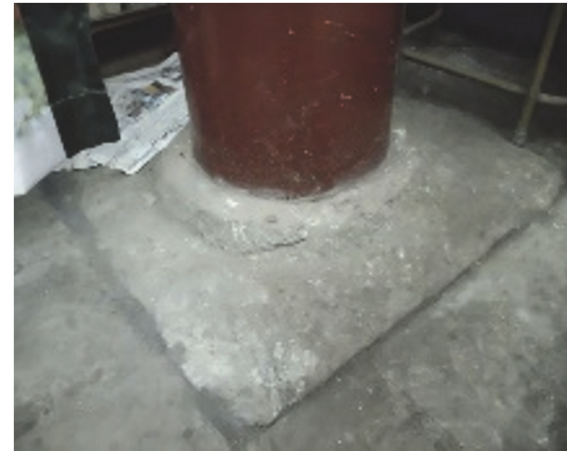

(a) Plinth damage

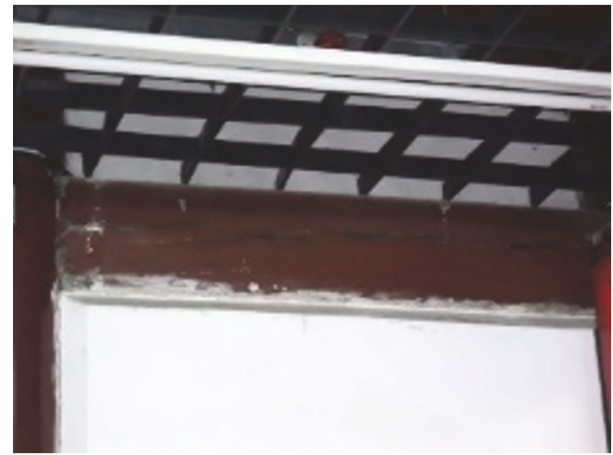

(c) Crack on fang

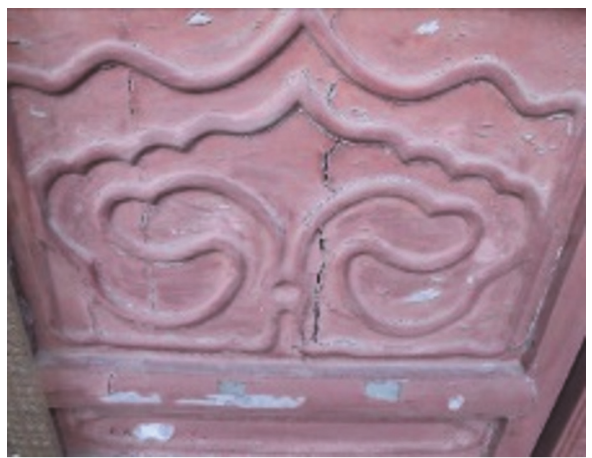

(e) Crack on door

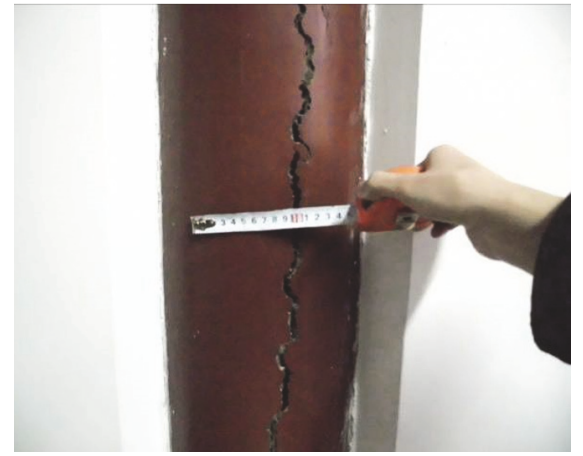

(b) Crack on column

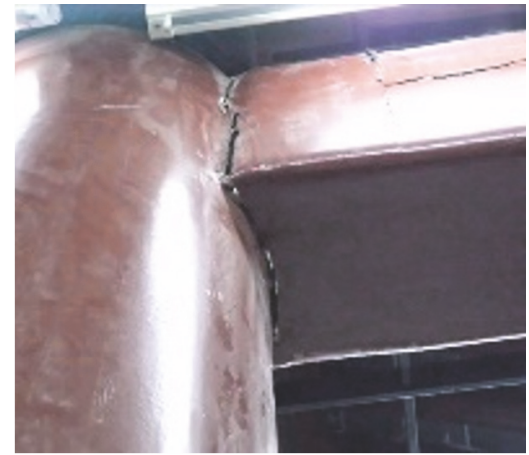

(d) Crack on the joint

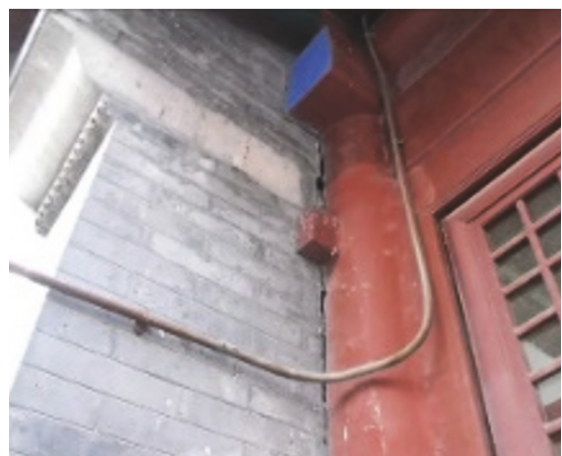

(f) Gable front skewed

FIgURE 3: External damage of the building.

\subsection{Incremental Dynamic Analysis}

5.2.1. Ground Motion Selection. A set of 100 ground motions are selected from the Pacific Earthquake Engineering Research (PEER) Center and used for earthquake input loading. According to the seismic fragility analysis carried out by Rota [23], Vafaei [24], and Hosseinpour [25], PGA, $P G V$, and $S a(T)$ can be used as indicators to describe earthquake intensity. Therefore, $P G A$ is selected in this study as the indicator of the intensity of ground motion.

5.2.2. Finite Element Model of the Components of the Rear Hall of the Huashi Fire God Temple. A three-dimensional finite element model is built by using the ANSYS software to evaluate the seismic global response of the rear hall of the Huashi Fire God Temple. Zhang [26] used beam element to simulate columns and beams of ancient timber buildings. So, in this paper beam element is used for the simulation of beams and columns, and spring element and shell element are selected for the simulation of mortise-tenon joints and roof of the ancient timber architecture. Reference [27] illustrated the roof structure of ancient timber architecture and offered bulk density of materials. Based on [27] and Chinese Code [28] load of the roof was calculated, which is $4030 \mathrm{~N} / \mathrm{m}^{2}$. Study [29] showed that mechanical properties of historic timber structure would decrease along with time and environment. Mechanical properties of the materials are appropriately reduced in the process of simulation, because the building has been in service for hundreds of years. The simplified finite element model is shown in Figure 4. 


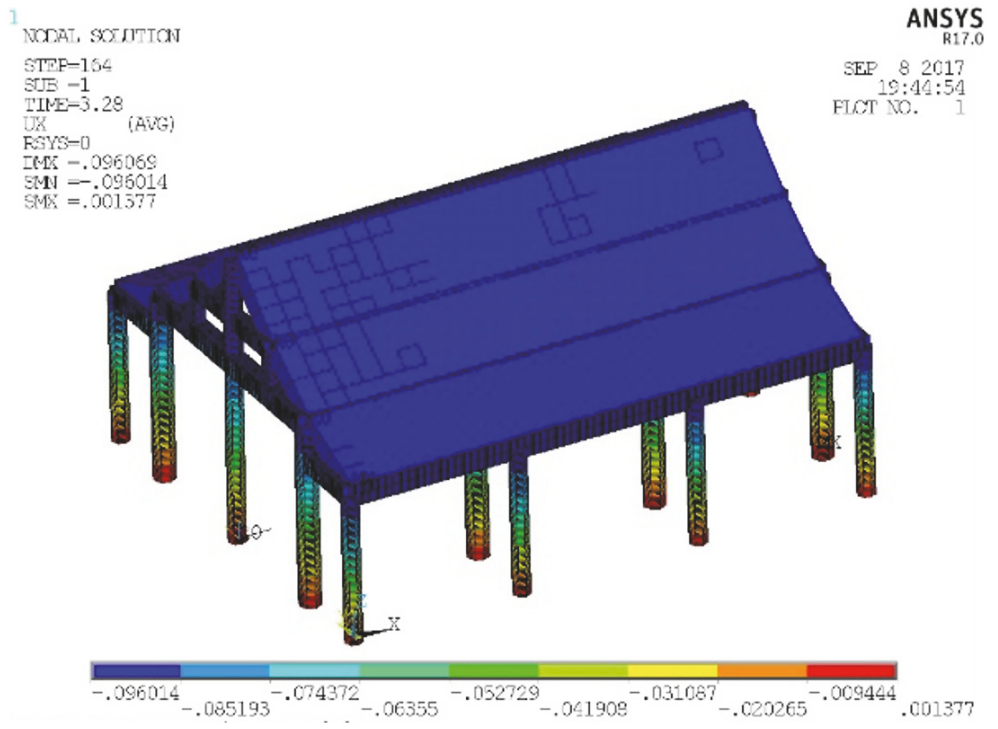

(a) Displacement in $\mathrm{X}$ with the excitation of EL Centro

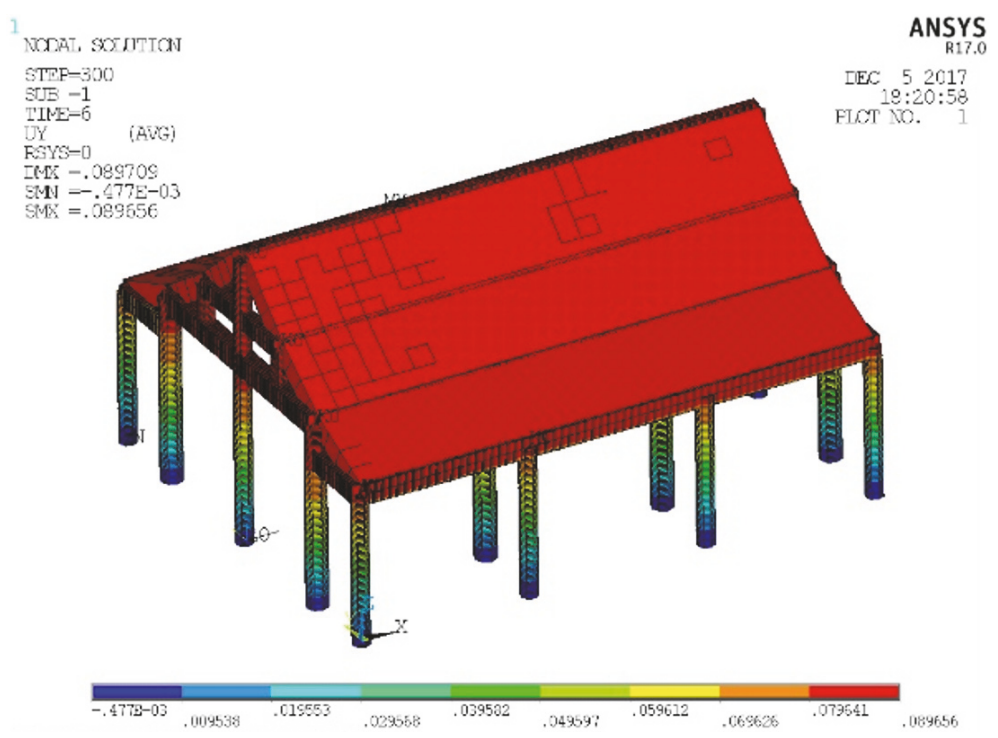

(b) Displacement in Y with the excitation of EL Centro

FIGURE 4: Simplified calculation model.

5.3. Mechanical Definition of Damage States. Wooden frames are main load-bearing system of ancient timber architecture. Mortise-tenon joints are unique connections between the components in ancient timber architecture. Seismic data [30], shaking table test carried out by Zhang et al. [31] and research carried out by Keita Ogawa [32] showed mortise-tenon joints are key points for ancient timber architectures. Li et al. [12] carried out a series of on-site test for Yingxian wood tower. They evaluated damages, bearing capacities, and reliability levels of the tower. And, a 1/10 scale shaking table test and nonlinear analysis of the wood tower were carried out. At last, a classification for seismic damaged levels and corresponding interstory drift ratio limitations based on shaking table test and nonlinear analysis was proposed in [12]. The classification is shown in Table 1. Zhang et al. [33] carried out a series of cyclic loading test of timber frames with mortise-tenon joints. Stiffness, energy dissipation, and bearing capacities of the frames were studied. They also described the pull-out length of tenon at different rotation angle of mortise-tenon joints and damage state. They found that the bigger the pull-out length of tenon, the more serious the damage of the frames. The study carried out by Institute of Earthquake Resistance and Disaster Reduction (IERDR) [34] proposed a damage classification levels for mortise-tenon joints. In the reference, damage levels are measured by pull-out length of tenon and damage degree. Based on $[33,34]$, the connection between the damage states and cosine rotation angle of mortise-tenon joints is shown in Table 1.

According to the results of the incremental dynamic analysis, a linear regression analysis is carried out based 


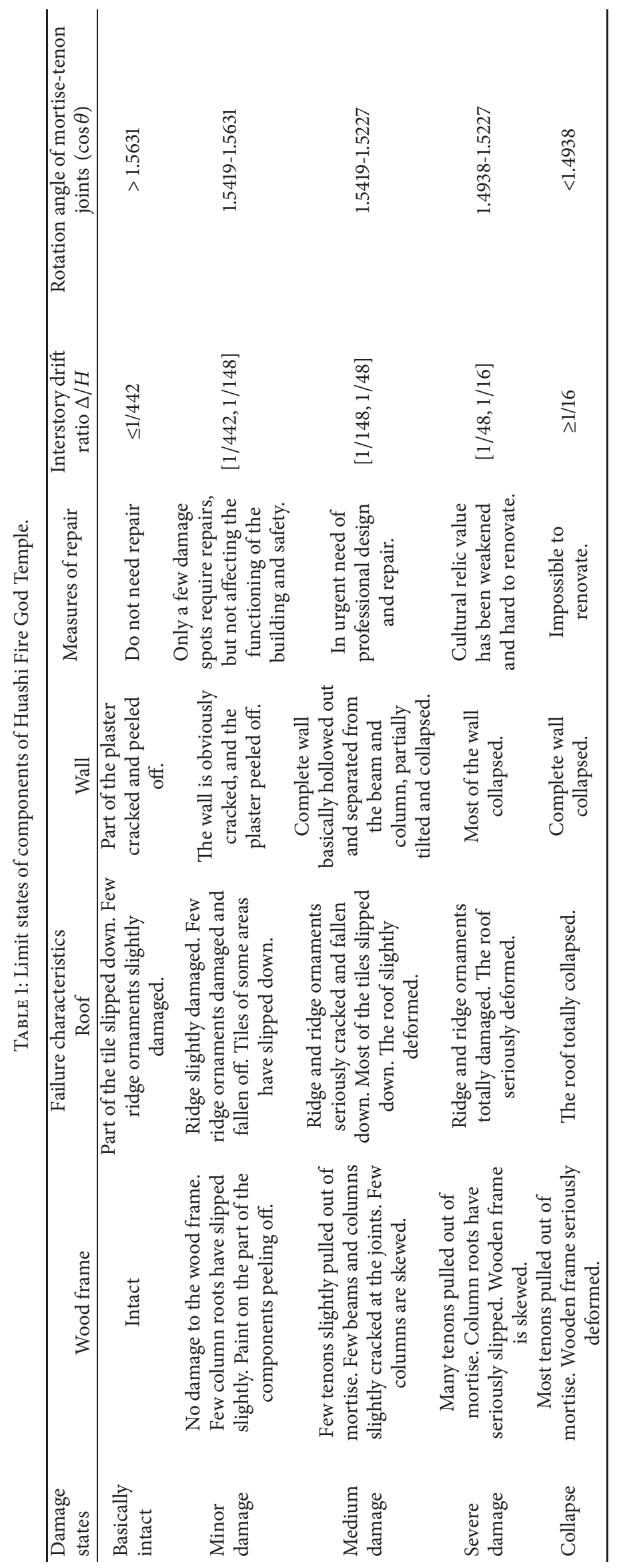


TABLE 2: Seismic demand models of components of Huashi Fire God Temple.

\begin{tabular}{lccc}
\hline Seismic demand parameters & Regression equation & Determination coefficients & Logarithmic standard deviation \\
\hline $\ln \left(\Delta_{x} / H\right)$ & $1.0745 \ln (P G A)-3.0056$ & 0.5767 & 1.3222 \\
$\ln \left(\Delta_{y} / H\right)$ & $1.0087 \ln (P G A)-3.0795$ & 0.6428 & 1.3147 \\
$\ln \left(\cos \theta_{x}\right)$ & $0.9880 \ln (P G A)-3.3871$ & 0.7035 & 1.3589 \\
$\ln \left(\cos \theta_{y}\right)$ & $0.9941 \ln (P G A)-3.2939$ & 0.6666 & 1.3463 \\
\hline
\end{tabular}

TABle 3: Gaussian Copula parameters.

\begin{tabular}{lcccc}
\hline Copula parameters & $\ln \left(\Delta_{x} / H\right)$ & $\ln \left(\Delta_{y} / H\right)$ & $\ln \left(\cos \theta_{x}\right)$ & 0.9803 \\
$\ln \left(\Delta_{x} / H\right)$ & 1 & 0.8716 & 0.8474 & 0.8411 \\
$\ln \left(\Delta_{y} / H\right)$ & 0.8716 & 1 & 1 & 0.9804 \\
$\ln \left(\cos \theta_{x}\right)$ & 0.9803 & 0.8474 & 0.8449 \\
$\ln \left(\cos \theta_{y}\right)$ & 0.8411 & 0.9804 & 0.8449 \\
\hline
\end{tabular}

$\Delta_{x} / H$ and $\Delta_{y} / H$ are interstory drift ratio in $\mathrm{X}$ and $\mathrm{Y}$ direction, respectively.

on least square method. Then, seismic demand models for different failure modes are built (Table 2). Copula parameters $\theta$ of different seismic demand parameters are used in this method to describe the correlations among different failure modes, which can be calculated by (9). For example, Table 3 shows the Gaussian Copula parameters of different failure modes. Table 3 shows the Gaussian Copula parameters range from 0.8 to 1 . This indicates that the failure modes are not completely linearly correlated, but the correlation effect is significant.

5.4. Fragility Curves for Single Failure Modes. By substituting the values given in Table 3 in (11) (13), the fragility curves for different failure modes are obtained and shown in Figure 5. $\sqrt{\beta_{n}{ }^{2}+\beta_{r}{ }^{2}}=1$ as suggested by Chen [35]. Figure 5 shows the comparison of the fragility curves in $\mathrm{X}$ and $\mathrm{Y}$ directions for different seismic demand parameters. It is observed that the rear hall extends more in the $\mathrm{X}$ direction. In particular, the failure probability in four damage states of the rear hall with the interstory drift ratio as seismic parameter is obviously greater than that with the rotation angle of mortise-tenon as seismic parameter. This indicates that consideration of the rotation angle of the mortise-tenon as the seismic parameter to assess the vulnerability of ancient timber architecture might underestimate the vulnerability of the structure.

\subsection{Fragility Curves with Correlation among \\ Different Failure Modes}

5.5.1. Fragility Curves Based on the Copulas. t Copula, Gaussian Copula, and Frank Copula are used to compute the fragility curves of the rear hall of the Huashi Fire God Temple. Comparison of the curves is shown in Figure 5. It is observed that the fragility curves obtained by Copulas are similar, and the occurrence probability is greater than any other failure modes. The highest vulnerability obtained is that calculated by Frank Copula function. With increasing $P G A$, the gap between the Copulas curves and others is increased. Therefore, when the earthquake intensity is high, the fragility curves based on a single seismic parameter might underestimate the vulnerability of ancient timber architecture.

5.5.2. First-Order Bound Method. In order to verify the accuracy of the Copulas, first-order boundary method was carried out to obtain the fragility curves of the rear hall. The formula for the calculation is given by

$$
\max _{i=1}^{m}\left[P_{i}\right] \leq P_{f_{s}} \leq 1-\prod_{i=1}^{m}\left[1-P_{i}\right]
$$

where $i$ and $m$ constitute the number of failure modes.

The upper and lower boundaries of the failure probability of different damage states of the rear hall of the Huashi Fire God Temple are obtained by using (15), which are shown in Figure 6.

It can be seen from Figure 6 that there is a marked deviation between the curves related to the upper and lower boundaries. The seismic vulnerability of the rear hall based on Gaussian Copula, Frank Copula, and t Copula lies between the curves related to the upper and lower boundaries of that based on the first-order bound method and is close to lower boundary.

\section{Conclusions}

This study investigates and analyzes the effect of correlation among the different failure modes on the seismic fragility of ancient timber architecture. A vulnerability assessment model for ancient timber architecture is established based on the finite element analysis theory and Copulas. In this model, different seismic demand parameters are adopted to obtain the fragility curves for different failure modes. This method takes into consideration the effect of correlation among the modes on the seismic fragility of buildings. This vulnerability assessment model is applied into a case study. The findings are as follows:

(1) When rotation angle of mortise-tenon and interstory drift ratio are taken as the seismic parameters to study the damage rates of the rear hall, the occurrence probability is different. It is obvious that the 


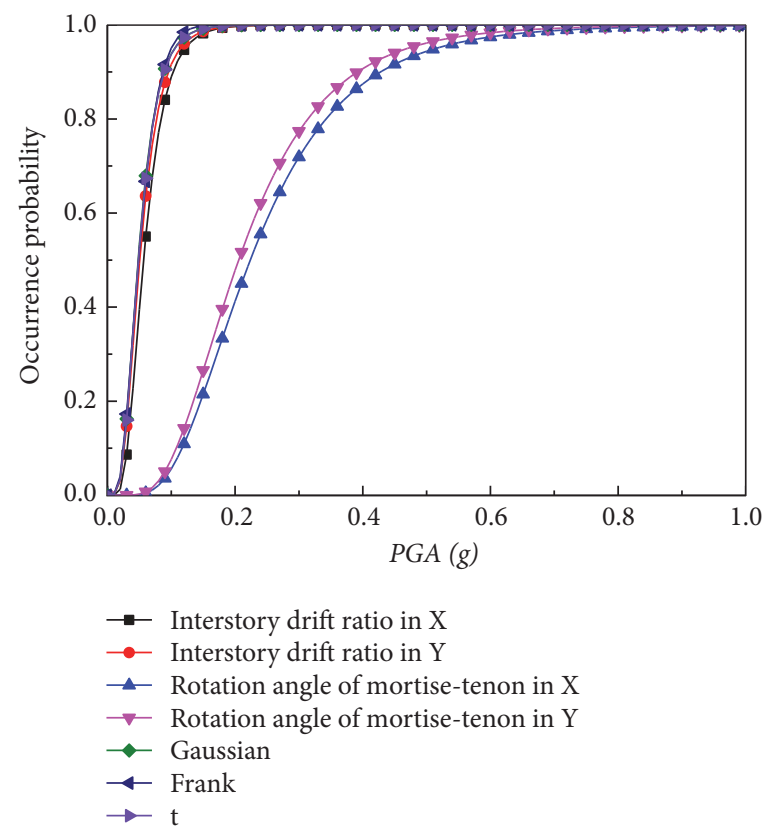

(a) Minor damage

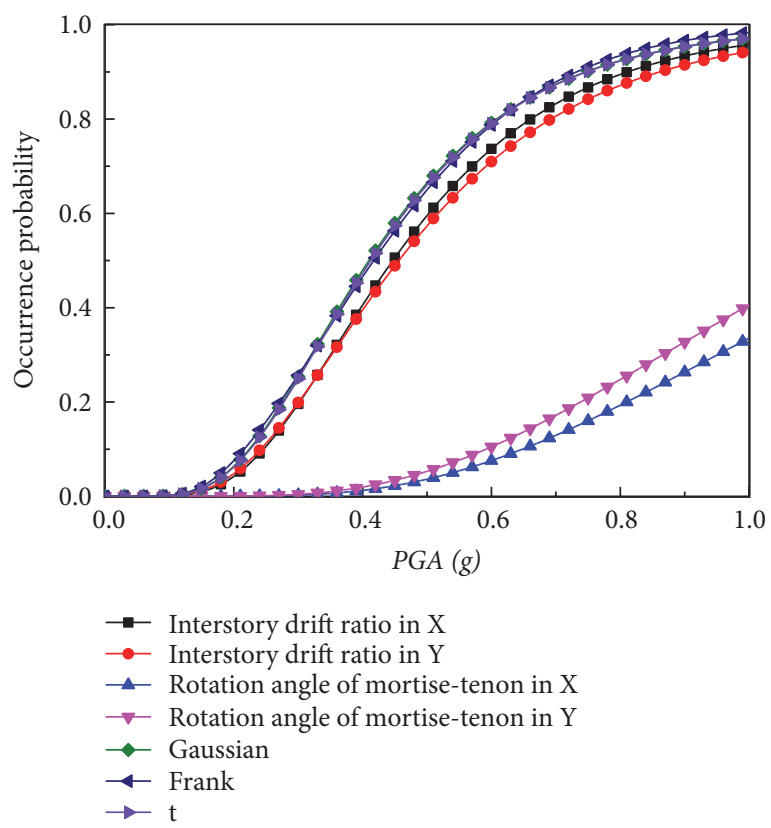

(c) Severe damage

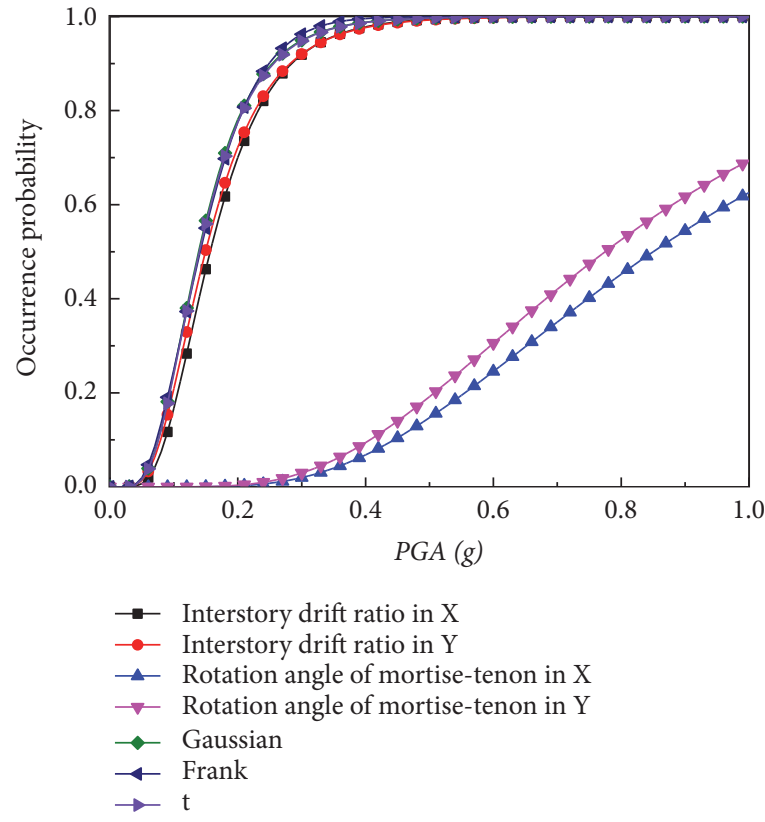

(b) Medium damage

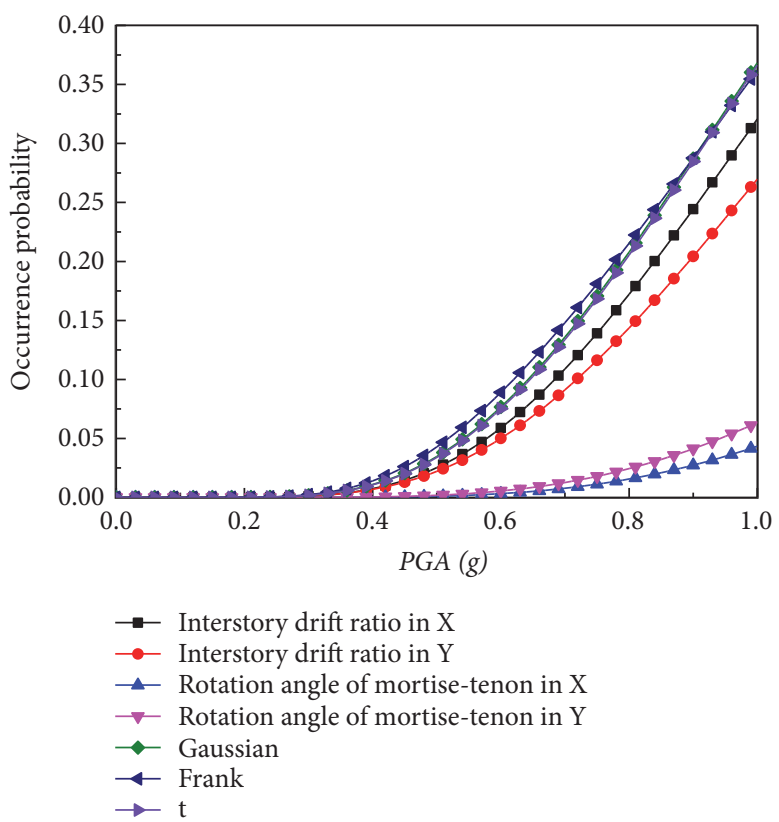

(d) Collapse

Figure 5: Fragility curves of rear hall Huashi Fire God Temple.

probability of the former is smaller than that of the latter. The smaller the occurrence probability is, the smaller the vulnerability is. This meant the values from the former would be below the ones from the latter. Therefore, the vulnerability of ancient timber architecture might be underestimated.

(2) The seismic vulnerability of timber architecture based on the Copulas is greater than that of any single failure mode. It indicated that seismic fragility analysis for ancient timber architectures based on single seismic failure mode might underestimate vulnerability of the structure.

(3) The first-order boundary method is performed to obtain the fragility curves. The obtained curves are compared with the calculated ones based on the Copulas. The comparison shows that the Copulas curves lie between the upper and lower boundaries in the first-order bound method. And the curves are close to the lower boundary. 


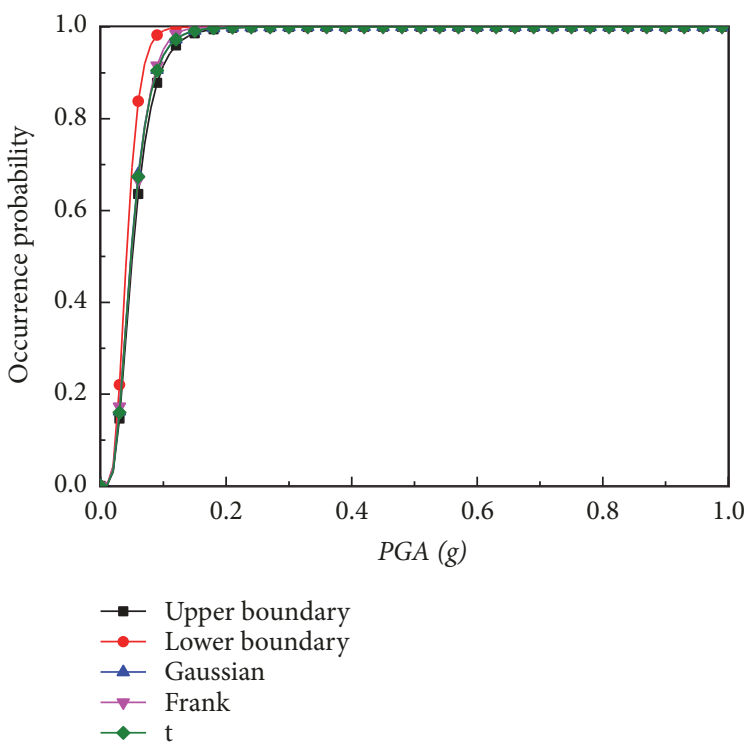

(a) Minor damage

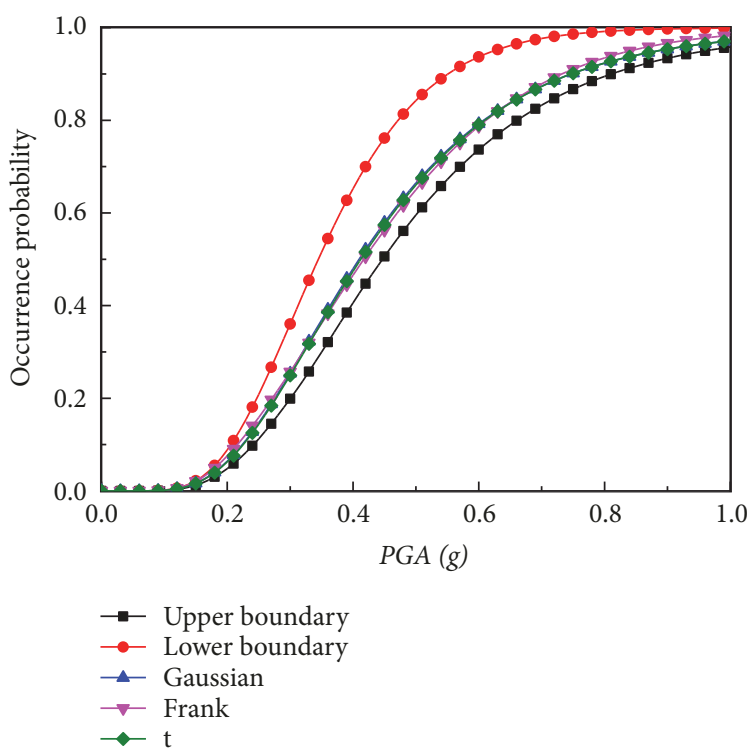

(c) Severe damage

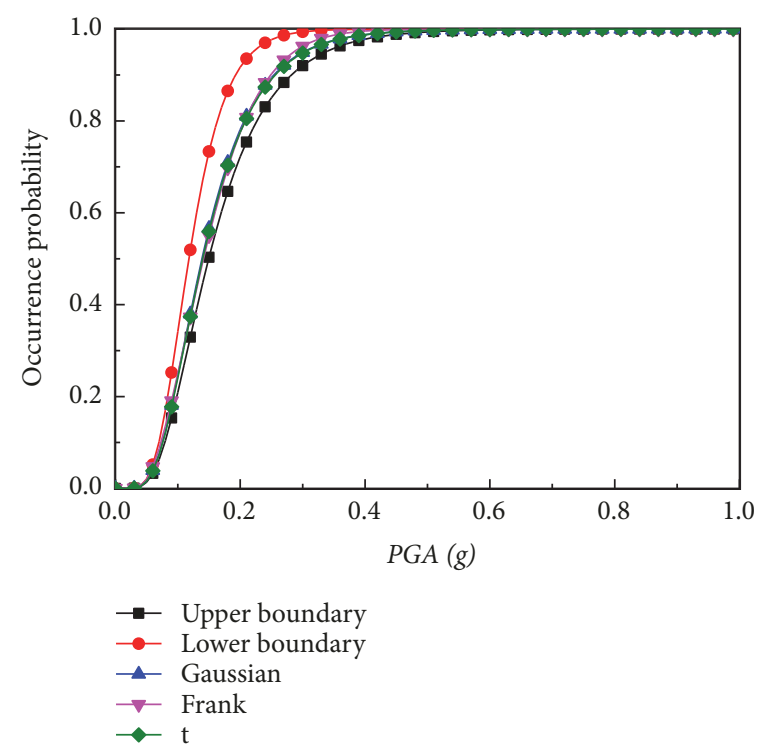

(b) Medium damage

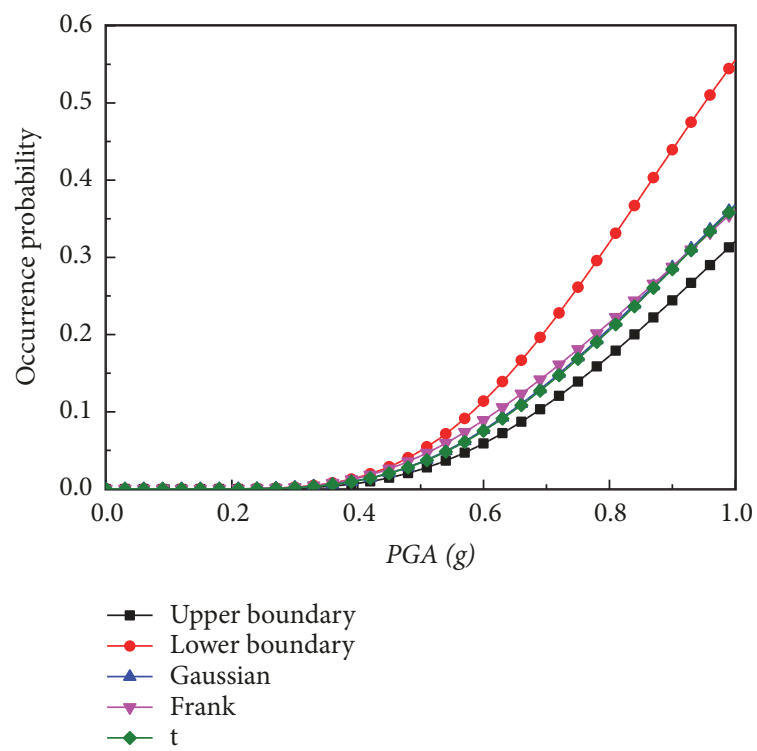

(d) Collapse

FIgURE 6: Fragility curves of the rear hall of the Huashi Fire God Temple.

(4) In future works, more failure modes need to be introduced in the research to enrich the data. The data might provide reliable seismic analysis, the comprehension would eventually enhance the accuracy of seismic vulnerability assessment. It was vital that appropriate seismic parameters be discovered to evaluate the vulnerability of ancient timber architecture.

\section{Data Availability}

The data used to support the findings of this study are available from the corresponding author upon request.

\section{Conflicts of Interest}

The authors declare that they have no conflicts of interest.

\section{Acknowledgments}

This study was financially supported by the National Natural Science Foundation of China (Grant No. 51678017, 51678005) and Beijing Municipal Education Commission Science and Technology General Project (Grant Nos. KM201610005029, KM201810005021, 8182008).

\section{References}

[1] H. Rao, B. Li, Y. Yang, Q. Ma, and C. Wang, "Proteomic identification of organic additives in the mortars of ancient Chinese wooden buildings," Analytical Methods, vol. 7, no. 1, pp. 143-149, 2015.

[2] Q. Xie, J. Xue, and H. Zhao, "Seismic damage investigation and analysis of ancient buildings in Wenchuan earthquake," Jianzhu 
Jiegou Xuebao/Journal of Building Structures, vol. 31, no. 2, pp. 18-23, 2010.

[3] A. Doǧangün, Ö. I. Tuluk, R. Livaoğlu, and R. Acar, “Traditional wooden buildings and their damages during earthquakes in Turkey," Engineering Failure Analysis, vol. 13, no. 6, pp. 981-996, 2006.

[4] N. Şahin Güçhan, "Observations on earthquake resistance of traditional timber-framed houses in Turkey," Building and Environment, vol. 42, no. 2, pp. 840-851, 2007.

[5] T. Rossetto and A. Elnashai, "Derivation of vulnerability functions for European-type RC structures based on observational data," Engineering Structures, vol. 25, no. 10, pp. 1241-1263, 2003.

[6] E. Dumova-Jovanoska, "Fragility curves for reinforced concrete structures in Skopje (Macedonia) region," Soil Dynamics and Earthquake Engineering, vol. 19, no. 6, pp. 455-466, 2000.

[7] J. Macabuag, T. Rossetto, and T. Lloyd, "Struct ural analysis for the generation of analytical tsunami fragility functions," in Proceedings of the 10th U.S. National Conference on Earthquake Engineering: Frontiers of Earthquake Engineering, NCEE 2014, USA, July 2014.

[8] L. S. Kouris and A. J. Kappos, "Derivation of fragility curves for traditional timber-framed masonry buildings using nonlinear static analysis," in Proceedings of the 4th International Conference on Computational Methods in Structural Dynamics and Earthquake Engineering, COMPDYN 2013, pp. 1339-1348, Greece, June 2013.

[9] C. Faye, Y. Verdret, and S. M. Elachachi, "Vulnerability analysis of conventional timber frame walls under seismic action," in Proceedings of the 2016 World Conference on Timber Engineering, WCTE 2016, Austria, August 2016.

[10] N. Ahmad, Q. Ali, and M. Umar, "Seismic vulnerability assessment of multistory timber braced frame traditional masonry structures," Advanced Materials Research, vol. 601, pp. 168-172, 2013.

[11] H. J. Blass, A. Ceccotti, C. Dyrbye et al., “Timber structures in seismic regions RILEM state-of-the-art report," Materials and Structures, vol. 27, no. 3, pp. 157-184, 1994.

[12] G. Hongzhi, Z. Yuhong, C. Hongbo, and L. Xiaoming, "A methord on forecasting the scale of a logistics center," China Civil Engineering Journal, vol. 38, no. 5, pp. 96-99, 2005.

[13] M. Sklar, "Fonctions de répartition à n dimensions et leurs marges," Publications de l'Institut de Statistique de l'Université de Paris, vol. 8, pp. 229-231, 1959.

[14] M. R. Fengler and O. Okhrin, "Managing risk with a realized copula parameter," Computational Statistics and Data Analysis, vol. 100, pp. 131-152, 2016.

[15] Y. Peng, K. Chen, H. Yan, and X. Yu, "Improving flood-risk analysis for confluence flooding control downstream using Copula Monte Carlo method," Journal of Hydrologic Engineering, vol. 22, no. 8, 2017.

[16] Y. Liu, H. Zhang, D. Li, Y. Deng, and N. Jiang, "Fatigue Reliability Assessment for Orthotropic Steel Deck Details Using Copulas: Application to Nan-Xi Yangtze River Bridge," Journal of Bridge Engineering, vol. 23, no. 1, 2018.

[17] S. Song, Y.-J. Qian, and G. Wu, "Research on seismic fragility method of bridge system based on copula function," Gongcheng Lixue/Engineering Mechanics, vol. 33, no. 11, pp. 193-207, 2016.

[18] M. Rota, A. Penna, and C. L. Strobbia, "Processing Italian damage data to derive typological fragility curves," Soil Dynamics and Earthquake Engineering, vol. 28, no. 10-11, pp. 933-947, 2008.
[19] C. A. Cornell, F. Jalayer, R. O. Hamburger, and D. A. Foutch, "Probabilistic basis for 2000 SAC federal emergency management agency steel moment frame guidelines," Journal of Structural Engineering, vol. 128, no. 4, pp. 526-533, 2002.

[20] R. B. Nelsen, An Introduction to Copulas, Springer, New York, NY, USA, 2nd edition, 2006.

[21] S. Liang, The ministry of works in qing dynasty, engineering practice rules, illustration, Tsinghua University Press, Beijing, 2006.

[22] W. Yin, H. Yamamoto, M. Yin, J. Gao, and S. Trifkovic, "Estimating the volume of large-size wood parts in historical timber-frame buildings of China: Case study of imperial palaces of the qing dynasty in Shenyang," Journal of Asian Architecture and Building Engineering, vol. 11, no. 2, pp. 321-326, 2012.

[23] M. Rota, A. Penna, and G. Magenes, "A methodology for deriving analytical fragility curves for masonry buildings based on stochastic nonlinear analyses," Engineering Structures, vol. 32, no. 5, pp. 1312-1323, 2010.

[24] M. Vafaei and S. C. Alih, "Seismic vulnerability of air traffic control towers," Natural Hazards, vol. 90, no. 2, pp. 803-822, 2018.

[25] F. Hosseinpour and A. E. Abdelnaby, "Fragility curves for RC frames under multiple earthquakes," Soil Dynamics and Earthquake Engineering, vol. 98, pp. 222-234, 2017.

[26] X. C. Zhang, Dynamic Analysis of Ancient Timber-Frame Buildings Under Seismic Excitations, PHD Thesis [Ph.D. thesis], Xian University of Architecture and Technology, 2013.

[27] T. Wang, Static Study of Ancient Large Wood frame architecture, Cultural Relics Publishing House, Beijing, 1992.

[28] GB. MOHURD, “50165-92-Technical Code for Maintenance and Strengthening of Ancient Timber Buildings," Tech. Rep., China Architecture Building Press, China Architecture, 1993.

[29] X. L. Wang, Research on Evaluation Method of Reliability-based Residual Life of Historic Timber Structure, PHD Thesis [Ph.D. thesis], Wuhan University of Technology, 2008.

[30] S. Q. Zhu, Preliminary Study on Seismic Damage of Heritage Wooden Structures in Wenchuan Earthquake. Institute of Engineering Mechanics, Master Thesis [Master, thesis], 2010.

[31] X. C. Zhang, J. Y. Xue, and H. T. Zhao, "Experimental study on Chinese ancient timber-frame building by shaking table test," Structural Engineering Mechanics, vol. 40, no. 4, pp. 453-469, 2011.

[32] K. Ogawa, Y. Sasaki, and M. Yamasaki, "Theoretical estimation of the mechanical performance of traditional mortise-tenon joint involving a gap," Journal of Wood Science, vol. 62, no. 3, pp. 242-250, 2016.

[33] F. Zhang, Q. Xu, J. Zhang, Q. Liu, and C. Gong, "Experimental study on seismic behavior of timber frames with mortise-tenon joints under different strengthening methods," Jianzhu Jiegou Xuebao/Journal of Building Structures, vol. 37, pp. 307-313, 2016.

[34] Earthquake Resistance and Disaster Reduction (IERDR). Report on the key technology of ancient timber architecture safety state evaluation, Institute of, 2016.

[35] T. Chen, Seismic Risk Assessment for Timber-Structure Ancient Architecture, Master Thesis [Master, thesis], Xian University of Architecture and Technology, 2013. 


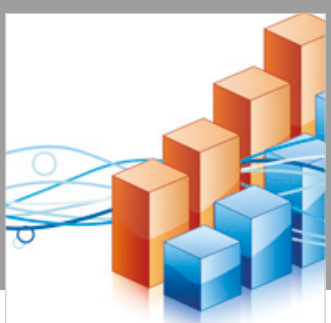

Advances in

Operations Research

\section{-n-m}
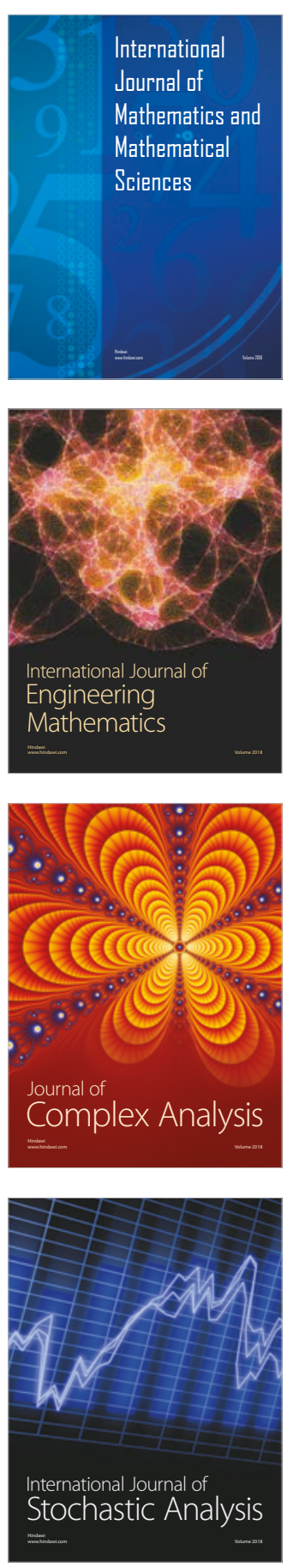
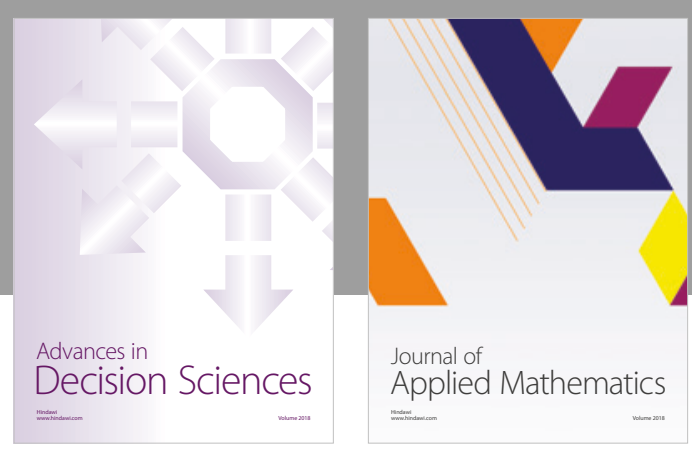

Journal of

Applied Mathematics
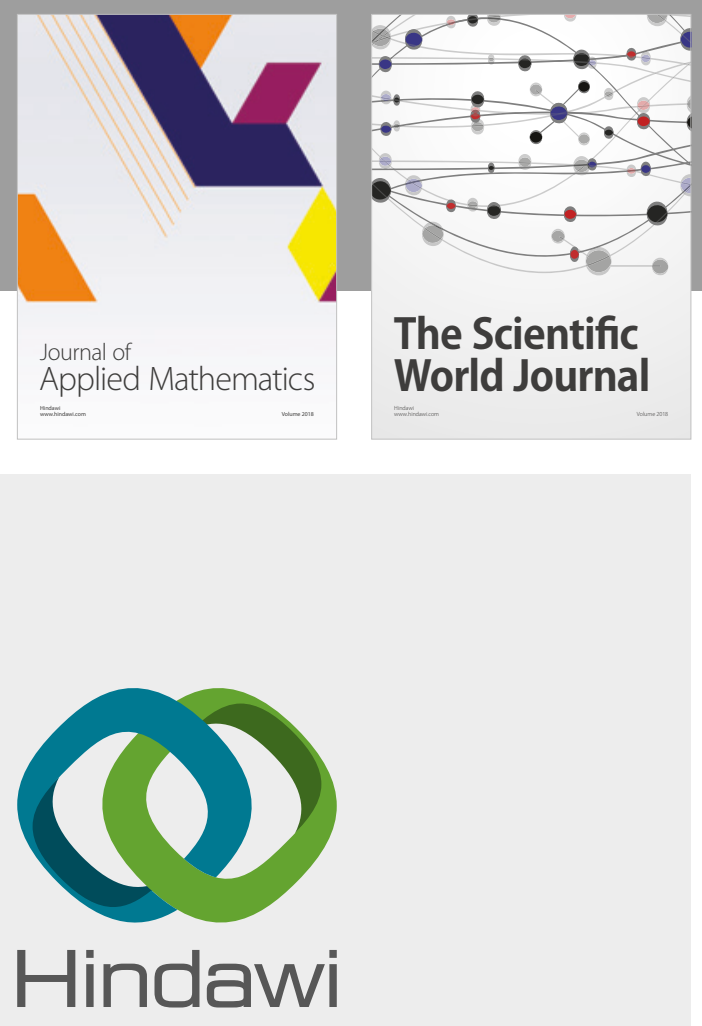

Submit your manuscripts at

www.hindawi.com

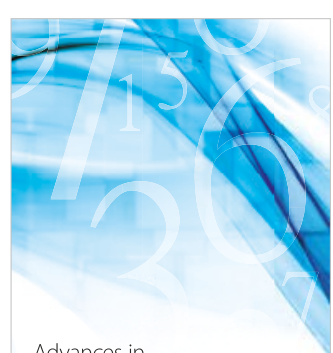

Advances in
Numerical Analysis
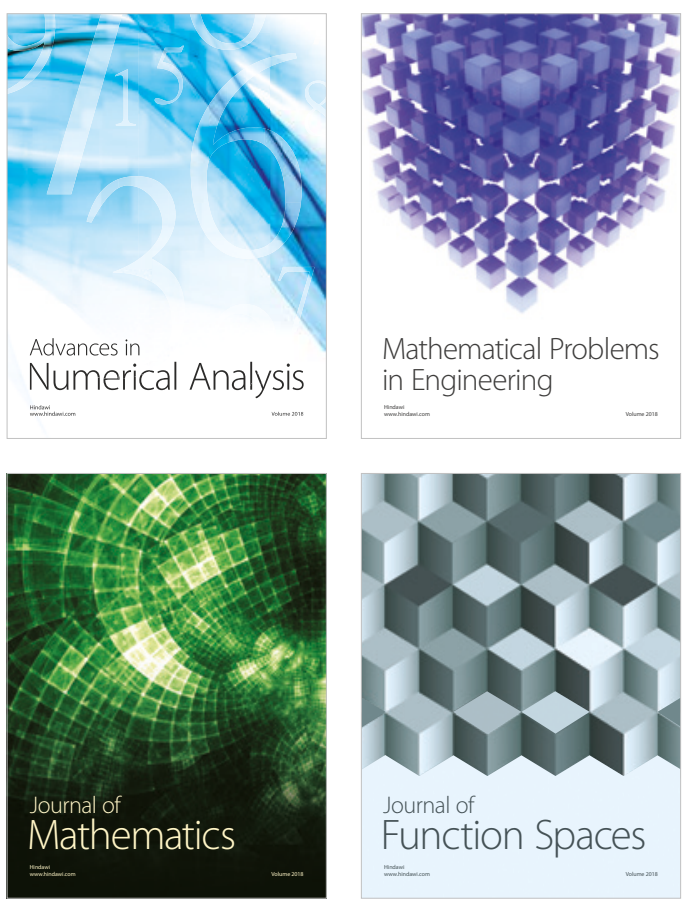

Mathematical Problems in Engineering

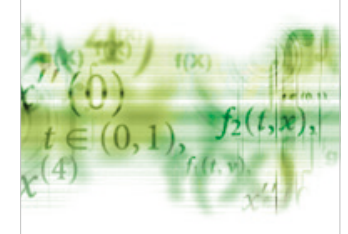

International Journal of

Differential Equations

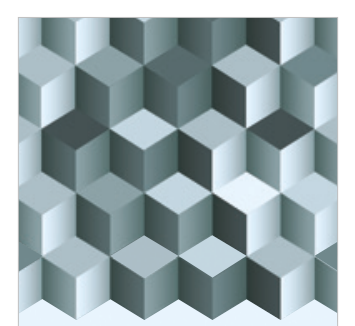

Journal of

Function Spaces

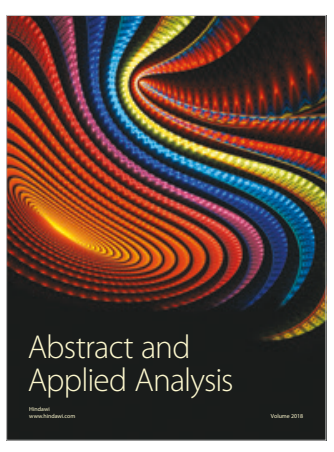

The Scientific

World Journal

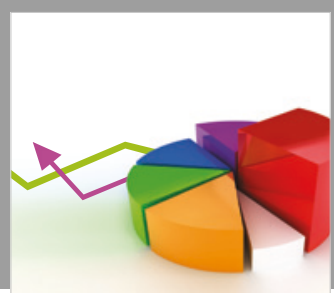

Journal of

Probability and Statistics
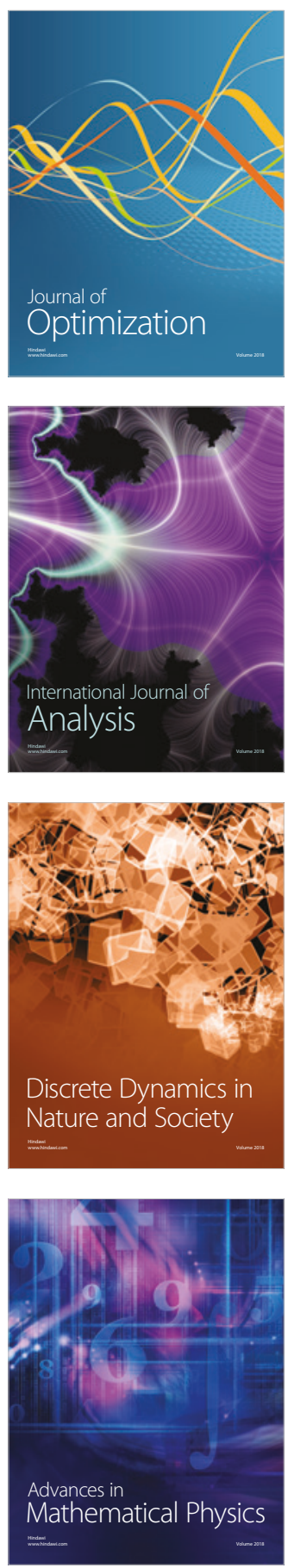